
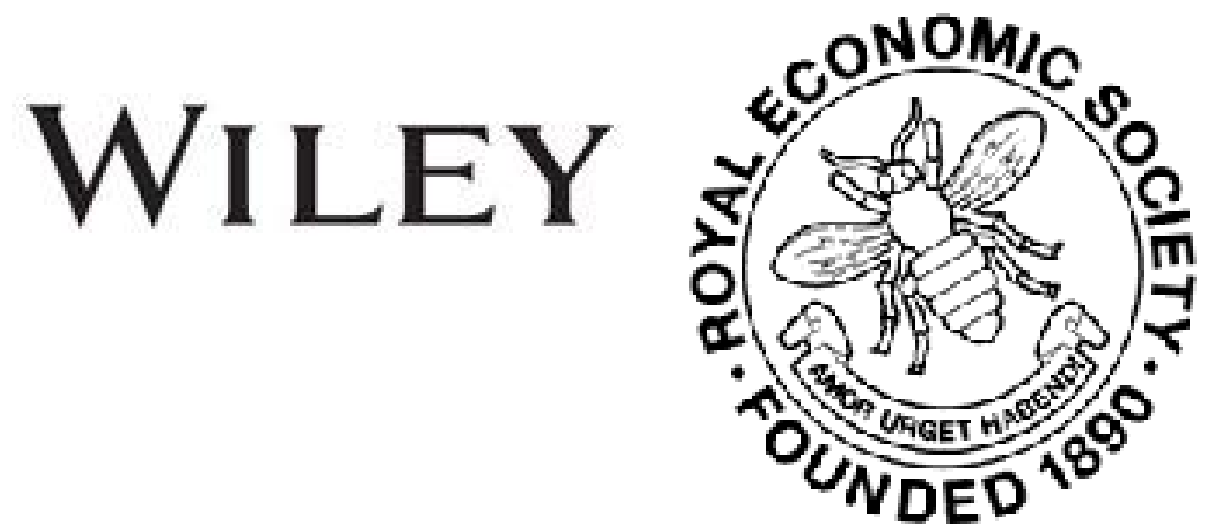

Recent Contributions to Economic History in Germany

Author(s): W. Hasbach

Source: The Economic Journal, Vol. 1, No. 3 (Sep., 1891), pp. 509-519

Published by: Wiley on behalf of the Royal Economic Society

Stable URL: http://www.jstor.org/stable/2956114

Accessed: 27-06-2016 02:28 UTC

Your use of the JSTOR archive indicates your acceptance of the Terms \& Conditions of Use, available at

http://about.jstor.org/terms

JSTOR is a not-for-profit service that helps scholars, researchers, and students discover, use, and build upon a wide range of content in a trusted digital archive. We use information technology and tools to increase productivity and facilitate new forms of scholarship. For more information about JSTOR, please contact support@jstor.org.

Wiley, Royal Economic Society are collaborating with JSTOR to digitize, preserve and extend access to The Economic Journal 


\section{RECENT CONTRIBUTIONS TO ECONOMIC HISTORY IN GERMANY}

WhEn I promised the Editor of the Economic Journal to give in one short essay a survey of the growth during the last few years of the literature of economic history in Germany, I believed it would be possible to condense within these narrow limits an epitome of the contents of each book, and briefly to indicate its special characteristics. To accomplish this I have confined myself generally to the last six years, 1885-90. I have eliminated all works of a strictly statistical, or strictly sociological nature, as for instance that by Lippert on the history of the family and the investigations in the history of property by Felix; I pass over the writings of Adler and Rosenthal on the organization of the State-administration in Austria; I do not mention even Roscher's essays on the typical features of certain political constitutions (Naturlehre)-even though they brilliantly illustrate his method. And yet there still remains so large a number of publications calling for notice, that I shall be content if, by classifying them accurately and giving a few words of description to the most important, I may effect something for the reader's guidance.

Beginning with researches in the borderland of our subject, we come first to a series of articles by Schmoller, which he has been publishing since 1889 in his Jahrbuch, treating of the phenomena of the division of labour and of the function of the entrepreneur, both of which he interprets in the light of historical development. In so doing he opens up an interesting perspective of what might be made of a theory of political economy upon a basis of historical sociology.

Turning from a confessed attempt to found afresh as well as reconstruct an existing science, we are confronted by efforts to instil a new spirit into the modern science of finance, which has 
won such ardent disciples in Germany since the days of the 'cameralists' (political scientists). Putting aside the older work of the lately deceased Lorenz von Stein, now in its fifth edition, I proceed to mention Roscher's Text-book of the Science of Finance ${ }^{1}$ (1886), the method of which follows, as far as is possible, the order of economic evolution in the body-politic and which is replete with data of historic life and thought. The Science of Finance ${ }^{2}$ (1889) by Gustav Cohn, as well as his somewhat earlier work, Principles of Political Economy ${ }^{3}$ (1885), exhibit the historical, and especially the ethical, tendencies in the development of political economy. Adolf Wagner himself, the author of the most scholarly and fundamental work on finance in the German language, while not belonging to the Historical School, has done justice as ever to this as to other forms of scientific effort, by compiling a history of taxation in the ancient world, and in Germany, France, and Great Britain in mediæval and modern times (1889). This remarkable production forms part of his text-book. ${ }^{4}$ Akin to these is a suggestive book by Vocke, the esteemed historian of British taxation, entitled Contributions, Imposts and Taxes in their Historical and Ethical Aspects $^{5}$ (1887), and which might otherwise be called the philosophy of the history of public contributions. It is possible that the author's preference for direct taxation has augmented the difficulties in the way of an absolutely disinterested consideration of the course of history, as well as of an unprejudiced judgment of other theories.

However that may be, the first volume of von BöhmBawerk's History and Criticism of the Theory of Interest ${ }^{6}$ (1884), is the work of a clear-headed, unbiassed historian of economic doctrines. Moreover an excellent history of the economic doctrines of price is to be found in a book On the Theory of Price 7 (1889), by Zuckerkandl, and a very interesting and incisive inquiry by Soetbeer into The Attitude of Socialists towards the Malthusian Theory of Population ${ }^{8}$ (1886).

Greater labours even have been expended on the history of economic literature. Two Spanish Mercantilists ${ }^{9}$ (1886), viz.--

1 System der Finanzwissenschaft.

3 Grundlegung der Nationalökonomie.

2 System der Finanzwissenschaft.

4 Lehrbuch der politischen Oekonomic; Finanzwissenschaft; dritter Theil; specielle Steuerlehre.

${ }_{5}$ Die Abgaben, Auflagen und die Steuer vom Standpunkte der Geschichte und der Sittlichkeit.

${ }^{6}$ Geschichte und Kritik der Kapitalainstheorien.

7 Zur Theorie des Preises.

8 Die Stellung der Socialisten zur Malthusischen Bevölkerungstheorie.

${ }^{9}$ Zwei spanische Merkantilisten. 
Uztariz and Ulloa, by Wirminghaus, is a contribution to a better understanding of the mercantile school so greatly calumniated by Adam Smith. Similar merit is due to Oncken, who has brought us to a deeper knowledge of the physiocrats by his essay The Elder Mirabeau and the Economic Society in Bern ${ }^{1}$ (1886), as well as by his interesting essay on The Maxim Laissez faire et laissez passer; its Origin and Formation ${ }^{2}$ (1886), and finally by editing the works of Quesnay (1888). In two essays published in the Tübinger Zeitschrift, 1889, 1891, Feilbogen treats of the relation of Adam Smith to Sir James Steuart and David Hume. Zeyss teaches us in his essay entitled Adam Smith and Selfinterest $^{3}$ (1889), what was the great English economist's general philosophy of life in its bearings on political economy. The writer of this essay has attempted to elucidate the philosophic principles which underlie the political economy founded by François Quesnay and Adam Smith. ${ }^{4}$ Mention should be made of Karl Walcker's Adam Smith the Founder of Political Economy ${ }^{5}$ (1890). The writer of this essay has recently published Inquiries Concerning Adam Smith and the Development of Political Economy ${ }^{6}$ (1891). Mr. Jenks, the American writer, has published a critical exposition of the theories of Henry C. Carey ${ }^{7}$ (1885). Nor has the literature of Socialism failed to find zealous students. Diehl has devoted a monograph of considerable length to Proudhon (1888, 1890). Then Dietzel, of repute as an acute theorist, is engaged in the production of an exhaustive work on Karl Rodbertus, two parts of which are already published $(1886,1888)$. But the highest level of intellectual excellence in this field is unquestionably attained by Schmoller in his work Contributions to a History of the Literature of Political and Social Science ${ }^{8}$ (1888), a collection of essays on certain eminent writers on political economy, distinguished by acute analysis, broad views, and a conciliatory attitude.

We come now into the domain of facts, where the books may be distinguished as purely historical or purely descriptive. Those

1 Der ältere Mirabeau und die ökonomische Gesellschaft in Bern.

2 Die Maxime laissez faire et laissez passer, ihr Ursprung, ihr Werden.

3 Adam Smith und der Eigennutz. Eine Untersuchung ilber die philosophischen Grundlagen der älteren Nationalökonomie.

4 Die Allgemeinen Philosophischen Grundlagen der von François Quesnay und Adam Smith begrilndeten Politischen Oekonomie.

5 Adam Smith der Begriinder der Politischen Oekonomie.

6 Untersuchungen iiber Adam Smith und die Entwicklung der Politischen Oekonomie.

7 Henry C. Carey als Nationalökonom.

8 Zur Litteraturgeschichte der Staats-und Socialwissenschaften. 
which combine in their treatment both development and present conditions I shall mention where appropriate.

Three monographs on population occupy a prominent position. The Population of the Graco-Roman World ${ }^{1}$ (1886), by Beloch is a compilation and a criticism of everything throwing light upon the circumstances of population in the ancient world. Jastrow's book on The Number of Inhabitants in German Towns at the End of the Middle Ages and at the Beginning of the Modern $\operatorname{Era}^{2}$ (1886), possesses, apart from the data it furnishes, a high theoretic value through the instruction imparted in the methods of investigation and in the courses pursued by research hitherto. Bücher, in an exhaustive work on The Population of Frankfurt-on-Main in the Fourteenth and Fifteenth Centuries ${ }^{3}$ (1886), has accomplished valuable and pregnant investigations, worthy of being classed with those of Schönberg and Schmoller.

Several economists have been engaged upon English political economy and social politics. An exhaustive work by Philippovich von Philippsberg, The Bank of England in the Service of the Fiscal Administration of the State 4 (1885), depicts the relations of that great credit-institution to the administration of the Treasury and public debts from its foundation up to the present day. Weyer in his book Factory Inspection in England ${ }^{5}$ (1888), gives a general account of English factory legislation, but makes the inspection of factories the central theme. To Faber we are indebted for a work of merit on The Rise of Agrarian Protection in England ${ }^{6}$ (1888). Von Schulze-Gävernitz has given us in his notable book Social Peace ${ }^{7}$ (1890) a picture of the social and political education of the English people in the nineteenth century. He has striven to show how the combined effect of labour unions, legislation, and the influence of men like Carlyle, the Christian Socialists, Pusey, Ruskin, Comte, Toynbee and others, has tended to lead England into the path of social peace.

Pringsheim has published Contributions to the History of Economic Development in the United Netherlands in the Seventeenth and Eighteenth Centuries ${ }^{8}$ (1890).

1 Die Bevölkerung der griechisch-römischen Welt.

2 Die Volkszahlen deutscher Städte zu Ende des Mittelalters und zu Beginn der Neuzeit.

${ }^{3}$ Die Bevölkerung von Frankfurt a/M. im 14. und im 15. Jahrhundert.

* Die Bank von England im Dienst der Finanzverwaltung des Staates.

5 Die englische Fabrikinspection.

${ }^{6}$ Die Entstehung des Agrarschutzes in England.

7 Zum socialen Frieden.

8 Beitràge zur wirtschaftlichen Entwickhungsgeschichte der vereinigten Niederlande im 17. und 18. Jahrhundert. 
The Economic Florescence of Spain in the Sixteenth Century and its Decay ${ }^{1}$ (1888), by Haebler, is the first work giving a connected account of the development of economic institutions in Spain. It contradicts the widespread assumption that the policy of Charles V. was responsible for their subsequent national decadence, and attaches a proportionately greater significance to the baneful influence of Philip II. and his successors.

One work only represents Italian economic history, viz., The Consulate of the Sea in Pisa ${ }^{2}$ (1888), an interesting monograph by Schaube, who has already published a work on the consulate of the sea in Genoa.

Johann von Keussler has recently completed his great work, A History and Criticism of Village Communal Tenure in Russia ${ }^{3}$ (1876-1887), a valuable contribution to the knowledge not only of Russia, but also of agrarian history in general. Further information concerning economic and social conditions in Russia is contained in Staehr's On the Origin, History, and Significance of the Russian Artel ${ }^{4}$ (1890), and in von Transehe-Roseneck's Landlord and Peasant in Livonia in the Seventeenth and. Eighteenth Centuries ${ }^{5}$ (1890).

Among contributors to the economic history of Switzerland Schanz stands pre-eminent as the author of a great work entitled Taxation in Switzerland and its Development since the Beginning of the Nineteenth Century ${ }^{6}(1890)$. This is a subject of special and manifold interest, due to the great variety of economic and ethnic conditions as well as the advanced stage of autonomy in the different cantons. Besides, the author does not strictly confine his view to the present century, but takes a retrospect of earlier stages of development.

The lion's share of all the research in economic history falls naturally to Germany. There is a wealth of interesting material in Lamprecht's extremely comprehensive work, Economic Life in Mediaval Germany ${ }^{7}$ (1886). It contains at once more and less than the title leads us to expect, the focus of his investigations being the cultivation of the soil in the Moselle districts.

Further investigations in mediæval times, of a highly meri-

1 Die wirtschaftliche Bliite Spaniens im 16. Jahrhundert und ihr Verfall.

2 Das Consulat des Meeres in Pisa.

${ }^{3}$ Zur Geschichte und Kritik des bäuerlichen Gemeindebesitzes in Russland.

${ }^{4}$ Ueber Ursprung, Geschichte und Bedeutung des russischen Artels.

5 Gutsherr und Bauer in Livland im 17. und 18. Jahrhundert.

${ }^{6}$ Die Steuern der Schweiz in ihrer Entwicklung seit Beginn des 19. Jahrhunderts.

7 Deutsches Wirtschaftsleben im Mittelalter.

No. 3.-VoL. I

$\mathrm{L} \mathrm{L}$ 
torious kind, if of more limited range, are Kruse's History of the Currency in Cologne down to the Year $1386^{1}$ (1888), Kostanecki's Public Credit in the Middle Ages ${ }^{2}$ (1889), Schoenlank's A History of the Journeymen of Old Nuremberg, ${ }^{3}$ published in Conrad's Jahrbiicher, 1889, and Nübling's The Cotton Industry in Ulm in the Middle Ages ${ }^{4}$ (1890), an inquiry of special merit from the great mass of data collected. The two works, The Politics of the Municipal Corn-trade in Germany during the Fifteenth, Sixteenth, and Seventeenth Centuries ${ }^{5}$ (1889), by Naudé, and Researches in the History of Commerce in Hamburg ${ }^{6}$ (1889), by Baasch, must be classed apart. Finally I should mention Bruder's Studies in the Financial Policy of Duke Rudolph IV. of Austria. ${ }^{7}$ This Duke Rudolph had instituted, as early as the year 1360, a general system of commuting rent and tithes, at first for Vienna and then for most of the provincial towns. Mention too should be made of the appearance a few months ago of Inama-Sternegg's longexpected book, The Economic History of Germany from the Tenth to the Twelfth Century ${ }^{8}$ (1891).

Hatscheck in The Manufactory on the Tabor in Vienna ${ }^{9}$ (1886) carries us back to the mercantilism of the seventeenth century, and describes the government institute designed by Becher to combine the functions of an industrial and educational workshop. The most important work on this period is that by Schmoller entitled Studies in the Economic Policy of Frederick the Great ${ }^{10}$ (Schmoller's Jahrbuch, 1884, \&c.). Here we have the advantage of seeing the economic policy of the great king clearly set forth, impartially appreciated, and defended against the criticisms of Liberals, and besides this an explanation of how so-called mercantilism is connected with the economic policy of the towns and the general policy of an absolute monarchy. The book is to a certain extent supplemented by Knapp's very lucid and impartial work entitled The Emancipation of the Peasant and the Origin of the Agricultural Labourer in the Older Parts of Prussia ${ }^{11}$ (1887).

1 Kölnische Geldgeschichte bis 1386.

2 Der öffentliche Credit im Mittelalter.

3 Zur Geschichte altnilrnbergischen Gesellenwesens.

4 Ulm's Baumwollweberei im Mittelalter.

5 Deutsche städtische Getreidehandelspolitik vom 15-17 Jahrhundert.

${ }^{6}$ Forschungen zur hamburgischen Handelsgeschichte.

7 Studien ilber die Finanzpolitik Herzog Rudolf IV. von Oesterreich.

8 Deutsche Wirtschaftsgeschichte vom 10-12 Jahrhundert.

9 Das Manufacturhaus auf dem Tabor in Wien.

${ }_{10}$ Studien iber die Wirtschaftspolitik Friedrich des Grossen.

11 Die Bauernbefreiung und der Ursprung der Landarbeiter in den älteren Teilen Preussens. 
The author in the first place sets forth the gradual development of manorial tenure and vassalage in Prussia to the east of the Elbe down to the beginning of the measures enacted by the kings of Prussia for the protection of the peasant. Secondly, he discloses the connecting links between the measures of the eighteenth century and the reforms of the Stein and Hardenberg ministries. With these two works, which have thrown so much light on the economic history of Prussia, we may class a number of able publications written by disciples of Schmoller and Knapp, e.g. The Decline of the Peasantry and the Rise of Manorial Tenure in New Hither-Pomerania and Riigen ${ }^{1}$ (1888), by Fuchs; On the Legal Relations between Landlord and Tenant in the Mark of Brandenburg from the Sixteenth to the Eighteenth Century; ${ }^{2}$ History of Taxation in Magdeburg from the Time of the Reformation down to the Eighteenth Century ${ }^{3}$ (1888), by Bielfeld; The Leading Reforms in Direct Rural Taxation in Prussia during the Eighteenth Century ${ }^{4}$ (1887), by Zakrzewski ; History of Prussian Fiscal Administration from 1766 to $1786^{5}$ (1888), by Schultze; and The Organization and Support of the Prussian National Militia in the Seven Years' War $^{6}$ (1888), by Schwartz.

The efforts made by Germany to found transpontine colonies have directed attention to the earlier colonial policy of Prussia, viz., in Schück's treatise on Colonial Policy in BrandenburgPrussia under the Great Elector and his Successors ${ }^{7}$ (1889), and in Frederick the Great's Asiatic Companies ${ }^{8}$ (1890), by Ring.

Longer periods are covered by such works as The Finding and Modelling of Amber and the Amber Trade in Prussia from the Time of the Order ${ }^{9}$ down to the Present Day ${ }^{10}$ (1887), by Tesdorpf ; Pforzheim in the Past ${ }^{11}$ (1889), by Gothein; The earliest Industrial

1 Der Untergang des Bauernstandes und das Aufkommen der Gutsherrschaften in Neuvorpommern und Rügen.

2 Ueber die gutsherrlich-bäuerlichen Rechtsverhältnisse in der Mark Brandenburg vom 16 bis 18 Jahrhundert.

${ }^{3}$ Geschichte des magdeburgischen Steuerwesens von der Reformationszeit bis in's 18. Jahrhundert.

${ }^{4}$ Die wichtigeren preussischen Reformen der directen ländlichen Steuern im 18. Jahrhundert.

5 Geschichte der preussischen Regieverwaltung von 1766-1786.

${ }^{6}$ Organisation und Verpflegung der preussischen Landmilizen im siebenjährigen Kriege.

7 Brandenburg-Preussens Colonialpolitik unter dem grossen Kurfursten und seinen Nachfolgern.

8 Die asiatischen Handlungscompagnien Friedrichs des Grossen.

9 i.e. of the knights of the "German Order."

${ }^{10}$ Gewinnung, Verarbeitung und Handel des Bernsteins in Preussen von der Ordenszeit bis zur Gegenwart.

11 Pforzheim's Vergangenheit. 
Associations in the Town of Wernigerode ${ }^{1}$ (1890), by Meister, who traces their history from the thirteenth down to the beginning of the present century, and Backhaus's Development of Agricultural Economy on the Domains of the Counts of StolbergWernigerode ${ }^{2}$ (1888).

In this work as well as in recently published works by Migerka and Herkner we come nearer to our own times. I allude to A Retrospect of the Woollen Industry in Briinn from 1765 to $1864^{3}$ (1890), by the former, and to The Cotton Industry and its Operations in Upper Alsace ${ }^{4}$ (1887), by the latter, who gives an account of the leading features in the development of this manufacture from the middle of the last century down to the present day. Akin to this book is Emanuel Sax's Domestic Industry in Thuringia, ${ }^{5}$ which has been recently completed, the first part having appeared in 1882 . Few works have so largely contributed to our knowledge of industrial circumstances in Germany. Lange has published a book On the Glass Manufacture in the Valley of Hirschberg ${ }^{6}$ (1889). Thanks to these, as well as to what Thun has written on the industries of the lower Rhine district, Bein on the industries of the Saxon Voigtland (1883-1884), and Schanz on colonization and industry in Franconia (1884), though a work of a more historic character, we can take a more enlightened view of the national situation. Nor must I omit Morgenstern's The Foundries of Fürth ${ }^{7}$ (1890), giving an account of the development of that industry from the beginning of the last century, and Zimmermann's book, The Florescence and Decline of the Linen Manufacture in Silesia $(1885)^{8}$ is valuable as the history of the development of a domestic industry.

Then we have Mamroth's comprehensive History of Taxation in Prussia, 1806-1816 ${ }^{9}$ (1890) ; The Administration of the Revenue in Baden from 1868 to $1889^{10}$ (1889), by Philippovich, an author I have already cited; an instructive inquiry into Population and Domestic Industry in the Kreis ${ }^{11}$ of Schmalkalden since the Begin-

1 Die ältesten gewerblichen Verbände der Stadt Wernigerode.

2 Entwicklung der Landwirtschaft auf den Gräflich Stolberg-Wernigerodischen Domänen.

3 Rückblick auf die Schafwollindustrie Brïnns, 1765-1864.

${ }_{4}$ Die oberelsässische Baumwollindustrie und ihre Arbeiter.

${ }_{5}^{5}$ Die Hausindustrie in Thilringen.

' Die Glas-industrie im Hirschberger Thal.

7 Die Fïrther Metallschläger.

8 Blilte und Verfall des Leinengewerbses in Schlesien.

9 Geschichte der preussischen Staatsbesteuerung, 1806-1816.

10 Der badische Staatshaushalt von 1868-1889.

11 Territorial unit of Central Government. 
ning of the Present Century ${ }^{1}$ (1887), by Frankenstein, who had also an interesting article on The Position of Working Women in German Cities ${ }^{2}$ (Schmoller's Jahrbuch, 1888); and Kramar's Paper Currency in Austria since $1848^{3}$ (1886), a work of great theoretic value, being an inductive inquiry into the causes of agio and its influence on political economy. Of similar character is Kral's Value of Money and the Movement in Prices in the German Empire 1871-1884 ${ }^{4}$ (1887).

Midway between the purely historical and the purely descriptive works stands Aschrott's book on The English Poor Law System, Past and Present ${ }^{5}$ (1886). The first volume, dealing with the historical development of English pauper legislation, contains nothing essentially new. The second, which is of greater scientific and practical importance, depicts the Poor Law in England as at present constituted. Schöne's essay, entitled Modern Developments in the Shoemaking Trade historically, statistically, and technically considered ${ }^{6}$ (1888), is mainly descriptive.

To the class of mainly descriptive works belong the writings of von der Leyen and of Sartorius von Waltershausen on social and economic circumstances in North America. The former published in 1885 a book on The Railways of North America; ${ }^{7}$ the latter followed in 1886 with a work on North American Trade Unions under the Influence of a Progressive Mechanism of Production. ${ }^{8}$ Both these works have materially enriched our knowledge of North America. Prison Labour ${ }^{9}$ (1888), by Faulkner, an American author, deals likewise with American matters. Special mention is called for by Sering's book, The Agricultural Competition of North America, Present and Future ${ }^{10}$ (1887). Of great scientific value in its all-round mastery of the subject, and its clear analysis of the different factors of which the agricultural competition of America is the outcome, it is the

${ }^{1}$ Bevölkerung und Hausindustrie im Kreise Schmalkalden seit Aufang dieses Jahrhunderts.

2 Die Lage der Arbeiterinnen in den deutschen Groszstädten.

3 Das Papiergeld in Oesterreich seit 1848.

${ }^{4}$ Geldwert und Preisbewegung im deutschen Reiche, 1871-1884.

5 Das englische Armenwesen in seiner historischen Entwicklung und in seinerheutigen Gestalt.

${ }^{6}$ Die moderne Entwicklung des Schuhmachergewerbes in historischer, statistischer und technischer Hinsicht.

7 Die nordamerikanischen Eisenbahnen.

8 Die nordamerikanischen Gewerkschaften unter dem Einfluss fortschreitender Productionstechnik.

$9^{\prime}$ Die Arbeit in den Gefängnissen.

10 Die landwirtschaftliche Concurrenz Nordamerikas in Gegenwart und Zukunft 
product, nevertheless, of eminently practical needs, and its proximate influence has been of a practical nature.

One volume only has so far appeared of Bärnreither's book, Labour Associations in England and their Law ${ }^{1}$ (1886). After a lengthy historical introduction, he discusses mainly the present condition of Friendly Societies in England in a thoroughgoing lucid manner.

Jansen, in The Economics of the Dutch Colonies in the Batta Districts ${ }^{2}$ (1886), and Thinkizi Nagai in The Economics of Agriculture in Japan in the Present and in the Future ${ }^{3}$ (1887) conduct us to the far East. The latter is a well-drawn picture of the present difficulties of land tenure and cultivation in Japan through the opening up of international commerce since 1868. Singer gives us many interesting aperçus of economic conditions in China in a lecture On Social Conditions in Eastern Asia ${ }^{4}$ (1888), but his reputation rests mainly on his excellent Examination of the Social Conditions in the Manufacturing Districts of North-east Bohemia ${ }^{5}$ (1885).

Sombart's well-written monograph on The Roman Campagna ${ }^{6}$ (1888) is for the most part descriptive. Worthy of note are also The Position of the Domestic Weavers in the Valley of the Weil ' (1886), by Kaerger. The Condition of the Alsatian Peasantry ${ }^{8}$ (1886), by Hertzog, and Contributions to the Present Position of Domestic Industry in Russia ${ }^{9}$ (1886), by Stellmacher. Post, in his book Model Establishments conducted on the Principle of Personal Care of the Entrepreneurs for their Employes ${ }^{10}$ (1889), has commenced to give an account of arrangements instituted by German employers for the well-being of their workmen. Other recent publications of the kind of literature in question are almost exclusively the outcome of the incentive of societies for promoting social reforms. Thus Böhmert's Account of the Poor Law Administration in Seventy-seven German Towns ${ }^{11}$ (1886), was

1 Die englischen Arbeiterverbände und ihr Recht.

2 Die hollandische Kolonialwirtschaft in den Battaländern.

3 Die Landwirtschaft Japan's, ihre Gegenwart und ihre Zukunft.

4 Ueber die sozialen Verhältnisse in Ostasien.

5 Untersuchungen ilber die sozialen Zustände in den Fabrikdistricten des nordöstlichen Böhmen.

6 Die romische Campagna.

7 Die Lage der Hausweber im Weilerthal.

${ }^{8}$ Die bäuerlichen Verhältnisse im Elsass.

9 Ein Beitrag zur Darstellung der Hausindustrie in Russland.

${ }_{10}$ Musterstätten persönlicher Fürsorge von Arbeitgebern für ihre Geschäftsangehörigen.

11 Darstellung des Armenwesens in 77 deutschen Städten. 
written at the instance of the Society for Improving the System of Poor Law Administration. ${ }^{1}$ The lion's share emanates from the Society for Promoting Social Reforms. ${ }^{2}$ For instance, from the data supplied by French, English, and Italian reports, a very clear and impartial account has been compiled by Reitzenstein, the recently deceased Nasse, and Eheberg, of the agrarian situation at the present day in France, England, and Italy (1884, 1886). Besides this, the same Society has instituted the compilation of reports on 'Rural Usury' (1887), on 'Labour Representatives' (1890), on ' German Domestic Industries' (1889, 1890), 'Strikes and Boards of Arbitration,' with an Introduction by Brentano, volumes of which have already been issued. In this connection there have appeared two interesting works by Stieda on 'Boards of Arbitration and Conciliation' (Gewerbegericht), and 'German Domestic Industry.'

These remarks may have sufficed to show the feverishly active development which political economy in Germany is undergoing in the direction of historical and descriptive analysis, in the efforts to bring the past to light and to enlarge the knowledge of present conditions. Several causes have combined to bring this about: the ascendency of the principles of the Historical School; the various problems of economic and social life, to solve which the need is felt of a sound basis supplied by a rich store of historic and descriptive materials; and last, not least, the vigorous incentive inspired by professors in German universities, notably by Professors Schmoller, of Berlin, Knapp, of Strassburg, and Conrad, of Halle. In this way a little army of scientific forces is being organized, without which the completion of the 'Dictionary of Political Science,' the second volume of which has just been published, would be an impossible undertaking, but which under actual conditions may be considered more or less as the most concentrated manifestation of scientific life in German political economy.

Finally, I may add that the completion of the third edition of Schönberg's Text-book of Political Economy may shortly be looked for.

1 Verein fïr Armenpflege und Woltätigkeit.

2 Verein fiir Sozialpolitik.

W. Hasbach 